\title{
CLUJ-NAPOCA - PREMISES OF A POTENTIALLY OVERCROWDED TOURIST DESTINATION
}

\author{
Alexandra BUZĂ ${ }^{*}$ \\ Faculty of Geography, Babeș-Bolyai University, 5-7 Clinicilor Street, 400006, Cluj-Napoca, Romania, \\ e-mail: buzaalexandra97@gmail.com \\ Olga POSTEUCĂ \\ Faculty of Geography, Babeș-Bolyai University, 5-7 Clinicilor Street, 400006, Cluj-Napoca, Romania, \\ e-mail: posteucaolga@gmail.com
}

Citation: Buză, A., \& Posteucă, O. (2020). Cluj-Napoca - Premises of a Potentially Overcrowded Tourist Destination. Analele Universitătii din Oradea, Seria Geografie, 30(2), 194-204. https://doi.org/10.30892/auog.302109-851

\begin{abstract}
Nowadays, several international tourist destinations are dealing with overtourism, which means a series of malfunctions concerning activity segregation (often, located in historical centres), discomfort for the local community and even for tourists, due to extended visiting hours, etc. In the same context, in a number of cities, local authorities came up with coping strategies regarding the management of tourist flow during travelling seasons and measures to avoid overcrowding on tourist attraction areas. We started our research with the purpose of validating the hypothesis according to which the city of ClujNapoca is confronting an intense travelling phenomenon and its consequences upon the citizens. In order to achieve this goal, a double social inquiry was considered, aiming at, on one hand, tourist perception of overtourism in the city of Cluj-Napoca (50 validated questionnaires), and citizen opinion in what regards tourist behaviour in Cluj-Napoca (166 validated questionnaires), on the other hand. The results of the research pointed out the following: a high interest in Cluj-Napoca tourist attractions, especially the ones located downtown; a tendency towards overtourism in the month of August, due to summer events, as well as overcrowded areas throughout the historical centre; the role of local administration in promoting the city of Cluj-Napoca as a travel destination; an everyday better image of the city as a destination for worldwide tourists etc.
\end{abstract}

Key words: tourist destination, social inquiry, cultural tourism, Romania, Cluj-Napoca

$$
* \quad * \quad * \quad * \quad * \quad *
$$

\section{INTRODUCTION}

In several cases, tourist destinations have been models of economic revival (Erschbamer et al., 2018). Hence, they become the key-element in tourism development, which, due to its well promoted potential through different branding techniques, lead to the development of certain 
identities and personalities in a pretty competitive environment, at national and international levels (Baloglu and Kozak, 2011). Tourist destinations distinguish from one another by their brand, image, value, quality, heritage etc. (Baloglu and Kozak, 2011; Herman et al., 2020a,b). Among the advantages that tourist destinations present in the context of local development, one can count: development of business environment, coming-up of medical services, development of educational environment, more expanded and modern urban areas, as well as communication and transport system. Moreover, according to Mutuku C. (2013), in time, around tourist destinations various products and tourist services have been created, whose consumption can be found under the same destination brand. Tourists perceive tourist destinations as unique entities that offer elements (accessibility, attractions, travel packages etc.) and basic experiences by means of which destinations differentiate themselves (Mutuku, 2013).

Many of the hotspot tourist destinations confront the phenomenon of overtourism (Erschbamer et al., 2018), as well as certain management aspects regarding tourist numbers. Some of these destinations have started to draw up plans in order to avoid overcrowding or limit the number of visitors (Pilato et al., 2018; Bourliataux-Lajoinie et al., 2019). The available literature on overtourism points out the consequences, and more specifically, the measures taken to limit tourist flow, decrease the phenomenon of tourismophobia (Bourliataux-Lajoinie et al., 2019; Paris, 2017; Petkar, 2017; Pilato et al., 2018; Khanali and Yazdi, 2017) or the creation of tourist educational policies (Bourliataux-Lajoinie et al., 2019). The notion of overtourism refers to certain overcrowded locations, which generates discomfort not only for tourists, but also for locals (Taiminen, 2018; Anuar et al., 2019; Egresi, 2018; Goodwin, 2017). Among the causes leading to this phenomenon we can name the freedom of mobility that leads to a constant flow of tourist masses (mass tourism) on a number of destinations (France, Spain, China etc.), the popularity of a tourist destination, the accessibility given by the freedom of travelling, the prices and the quality of tourist services (Erschbamer et al., 2018). The negative effects on tourist destinations may vary from one destination to another, but, considering Barcelona, as one of the hotspot destinations for mass tourism - „Spain counts with 77 million visitors in 2017" (Taiminen, 2018; Kottasova, 2017), we speak of aesthetic and functional changes of the city, through new accomodation structures being set up, new aesthetics of public squares, all due to the massive internationalisation of the city environment and atmosphere, lack of social cohesion, local attitude towards tourists (Ballester, 2016).

Overtourism is an effect produced by urban cultural tourism, a type of tourism dating back in ancient times, when it was known under other forms. Urban areas (urban jams/cities) represent travel locations in which $50 \%$ of the population is urbanized (Cave and Jolliffe, 2012). Some of the causes leading to this type of tourism were the cultural and economic development of urban centres and the presence of architectural styles in buildings. In an urban environment, tourism is dependent on the presence of cultural attractions, on spare time spent to relax, exchange of values, ideas and cultural experiences (Bogdan, 2019). The cities were proved to be polarizing nuclei of attraction (Puşcaş, 2015; Herman et al., 2020c). According to Bogdan E. (2019), urban tourism may be of help in saving and conserving cultural heritage, by means of the local-visitor interaction.

From the legislative point of view, there are no EU integrated directives meant to contribute better management of mass tourism or constant flow of tourists (European Parliament, 2015). Tourism is a sector of economic activity which contributes over $10 \%$ to the EU GDP, and it is also a job-generator (over 12\%).

Some of the European countries have created their own systems of fighting mass tourism, which is the main factor leading to overtourism. In Spain, Barcelona has been confronting for years this overtourism phenomenon; under such circumstances, a management plan was drawn up, entailing better management and tax on new accomodation structures, declaring tourist-purchased properties illegal, cooperation with local authorities to fight illegal residence (Goodwin, 2017). In The Netherlands, Amsterdam may be considered as another example of a city touristically developed which is confronting overtourism, but a few years ago the Dutch authorities launched a programme called City in Balance which implies keeping a balance between visitors and residents, 
on the idea that ,visitors are welcome, but locals are the priority”. Moreover, traffic restrictions were imposed in the city central areas, homogeneity of accomodation structures is aimed at, and a series of campaigns sustaining responsible tourism are being organised (Hospers, 2019). Other European destinations which started to fight this phenomenon: in Prague, the presence of vehicles in the central historical area is forbidden; in Denmark, the purchasing of residences by foreigners, all along the coast, is forbidden, and in Copenhagen the opening of new bars and restaurants is also forbidden (Goodwin, 2017). The Cultural Entreprise for Management of Equipment and Cultural Animation was founded in Lisbon (EGEAC), financed through collecting entrance tickets at Sao Jorge Castle (Marques and Richards, 2019).

The United Nations World Tourism Organization (UNWTO) comes up with generally valid solutions to fight overtourism, such as: strategies to diversify the existing tourist and travel supplies, extended areas of tourist attractions, a reduced travelling season and management strategies for tourist areas (Egresi, 2018; Coldwell, 2017).

The phenomenon of rejection and antipathy towards tourists, felt by locals, is called tourismophobia and is very common in overcrowded popular destinations (Egresi, 2018). It was mentioned for the first time in the media around Barcelona, and the notion was used to describe the rejection of tourist masses by residents (Krugzek, 2019; Milano, 2017; Martin et al., 2018). The phenomenon entails verbal and physical threats towards tourists, and also towards accomodation structures, as prices went up and local lifestyle has changed (Egresi, 2018). Even local authorities feel, sometimes, that they have no arms to fight this situation (Milano et al., 2018); consequently, there should always be a balance between locals and tourists, and the process of gentrification by restoring the suburbs and poor peripheral areas may be a solution to this (Egresi, 2018; Niţulescu, 2006).

Most tourists are attracted by those destinations with a balanced price-offer ratio. Low-cost companies promoted heavily certain destinations, new types of accomodation came up (Airbnb), located in the city centres, which soon turned out to be overcrowded (Paris, Londra, Barcelona) (Egresi, 2018). Another aspect caused by mass tourism in some destinations is the loss of local identity (Egresi, 2018). At the same time, a good example of tourismophobia is Palma de Mallorca, where, in the past, the Aborigine population would welcome tourists happily, but nowadays they feel fear towards them. They see tourists as being responsible for their overcrowded city, price increase and alteration of lifestyle (Ballester P., 2016).

The purpose of this research is to draw attention on the phenomenon of overtourism, its causes and effects on the most popular tourist destinations, as well as management strategies and measures of fight against it. Particularly, we started with the hypothesis of validating the premise according to which the city of Cluj-Napoca is an ever-developing tourist destination confronting certain premises of an individualized overtourism phenomenon.

\section{METHODOLOGY}

\section{Research area}

The city of Cluj-Napoca is one of the most important urban centres in Romania and one of the most popular tourist destinations in Transylvania. Apart from being an old city, Cluj-Napoca is also a prominent cultural nucleus, a great academic and business centre (Popescu and Grigoraş, 2018), with a series of anthropic and natural tourist attractions (Cosma, 2006), such as St. Michael Church, The „Babeş Bolyai” University main building, Matei Corvin House, The Botanical Gardens or The Ethnographic Museum (Figure 1).

Moreover, Cluj-Napoca is a hotspot destination due to its cultural events (Popescu and Grigoraş, 2018), as it holds a pretty rich and stable calendar of events (Cosma, 2006) and international festivals, which contributed to the increase of its popularity as a travel destination. Cultural events are the most dinamic elements that contribute a greater flow of tourists (Cosma, 2006). In 2015, the city was granted the title of European Youth Capital, and in 2017 that of European Sports Capital. In 2017, more than 1.100 events and over 3.500 activities were organised, which attracted over 21\% of the tourists (Popescu and Grigoraş, 2018). Each year, the city hosts 
popular festivals: Untold, Jazz in the Park, Transylvania International Film Festival (TIFF), Street Food Festival, Cluj-Napoca Music Autumn Festival etc.

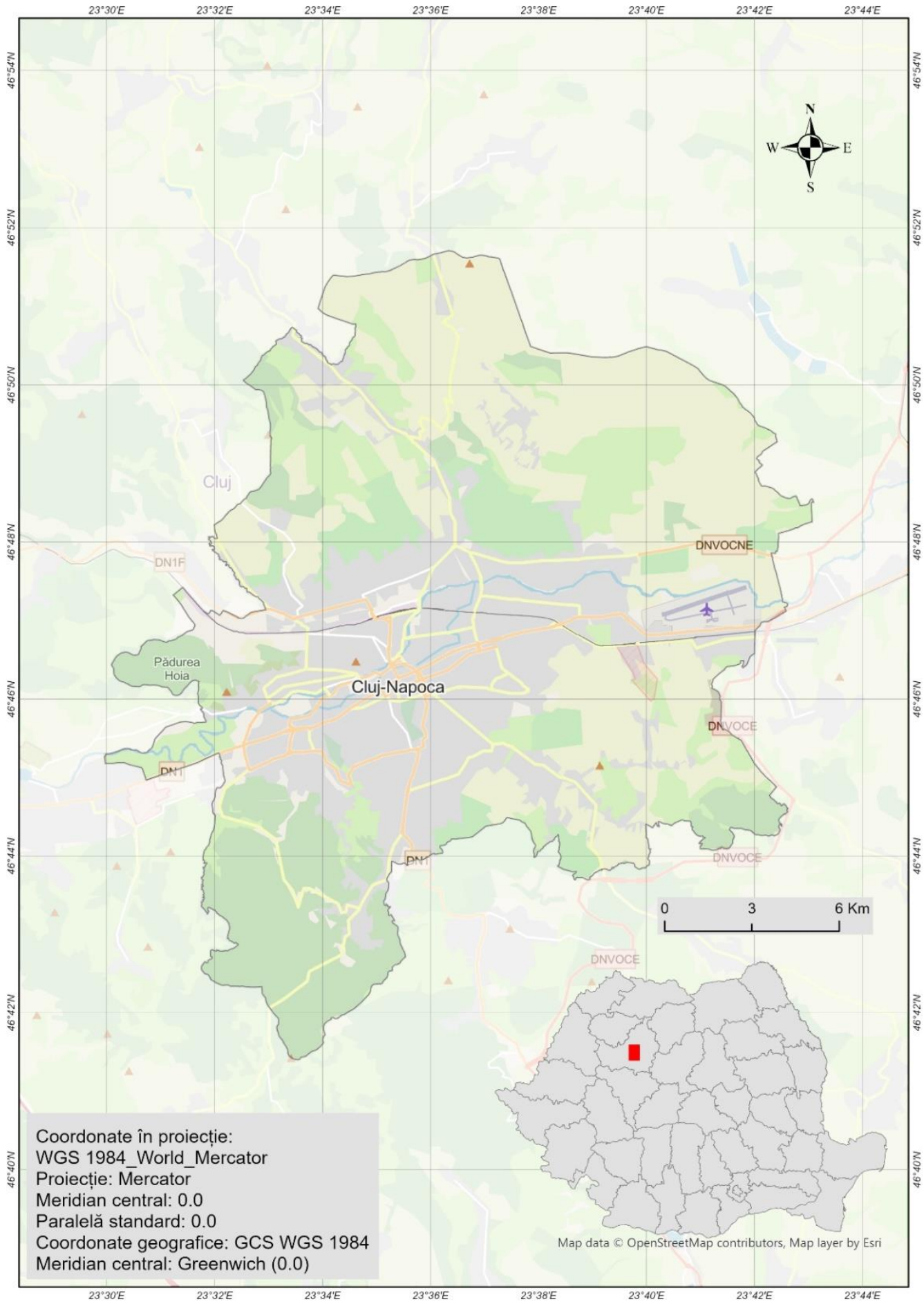

Figure 1. Placement of research area 


\section{Methods used}

Apart from the fact that the available literature on overtourism has been consulted, the method of social inquiry has also been used, by means of a double set of questionnaires meant to shed light on the perception of locals, and also on that of tourists towards Cluj-Napoca as a travel destination. The questionnaires were undertaken in December 2019 - March 2020. They consisted of two sets of items: one for locals (166 validated questionnaires), and the other one for tourists ( 50 validated questionnaires). The role of the questionnaires was that of collecting answers associated to the tourism phenomenon to be researched (Cosma, 2006; Anuar et al., 2019).

In the case of the first set, addressed to tourists, the conclusion was that all respondents were foreigners, mainly from Germany and Israel, without Romanian citizenship (Figure 2.1-2.6.).
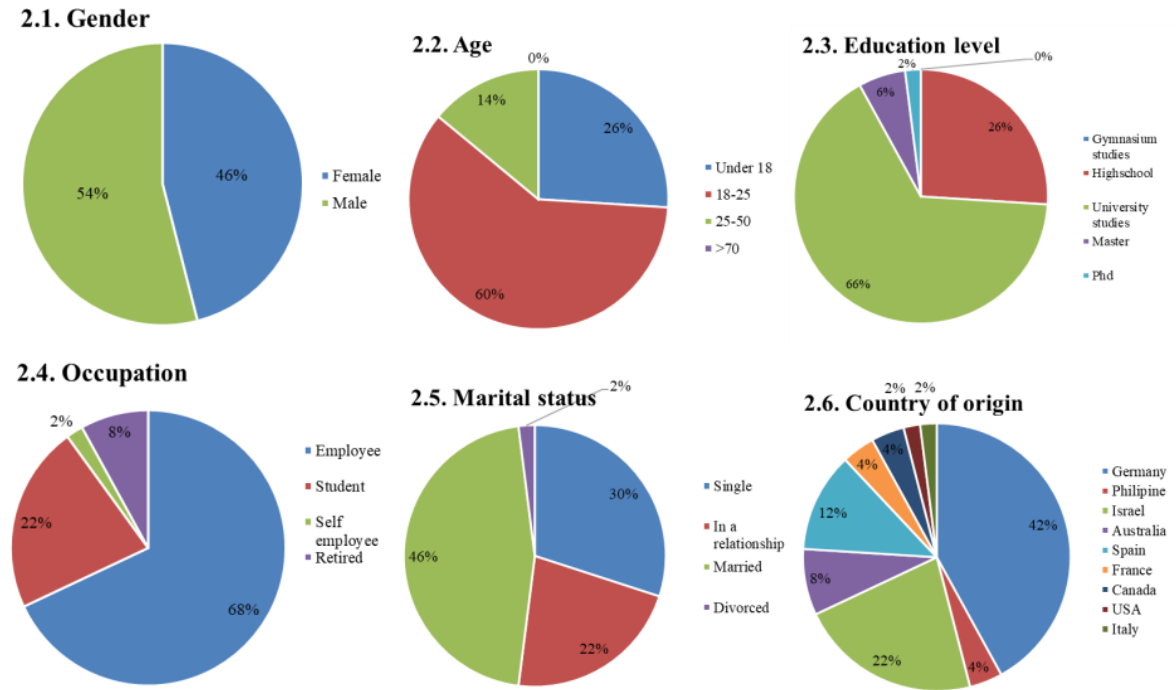

Figure 2. Social-demographic characteristics of respondents (tourists)

As for the second set, addressed to locals, the respondents were mainly students, aged 18-25, mainly females (Figure 3.1-3.5).
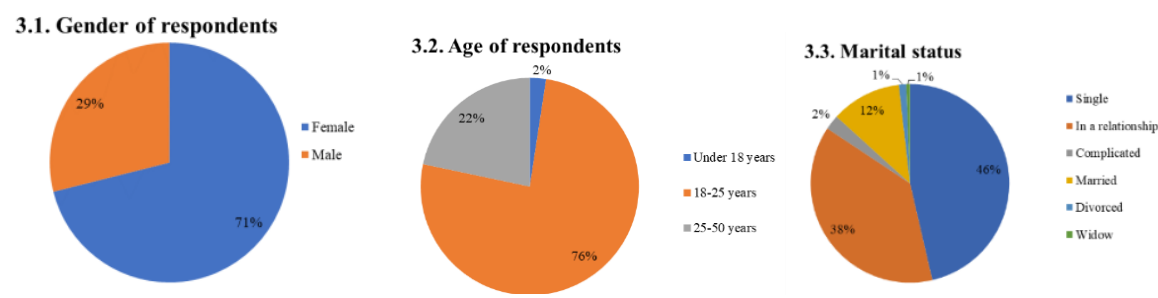

3.4. Education level

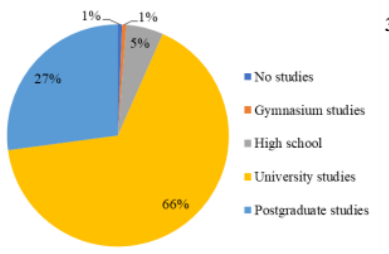

3.5. Occupation

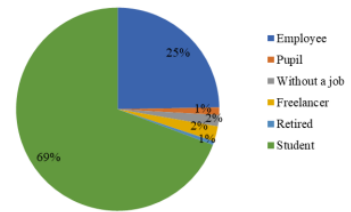

Figure 3. Social-demographic characteristics of respondents (locals) 


\section{RESULTS}

\section{Cluj-Napoca - tourist destination}

Cluj-Napoca belongs to the category of the most visited tourist destinations in Romania, and its contributing multicultural component is more than visible (Cosma and Negrusa, 2008). The city offers a variety of tourist attractions (Figure 4) (Ministry of Culture, 2015), consisting of: a series of anthropic tourist attractions, such as buildings and institutions, historical buildings belonging to different historical periods, churches, palaces, public squares; a whole variety of cultural, sports and artistic events: Transylvania International Film Festival (TIFF), Cluj Anniversary Days, Hungarian Cultural Anniversary, Untold, Jazz in the Park, Book Fest etc.; an attractive natural space consisting of green areas (the banks of Someş river, Hoia Baciu Forest, Făget Forest, „Alexandru Borza” Botanical Gardens, „Simion Bărnuţiu” Central Park).

Although the city of Cluj-Napoca does not boast tourist attractions and monuments classified by the UNESCO, it defines itself as an appealing destination at European level (Bolog et al., 2014-2020).
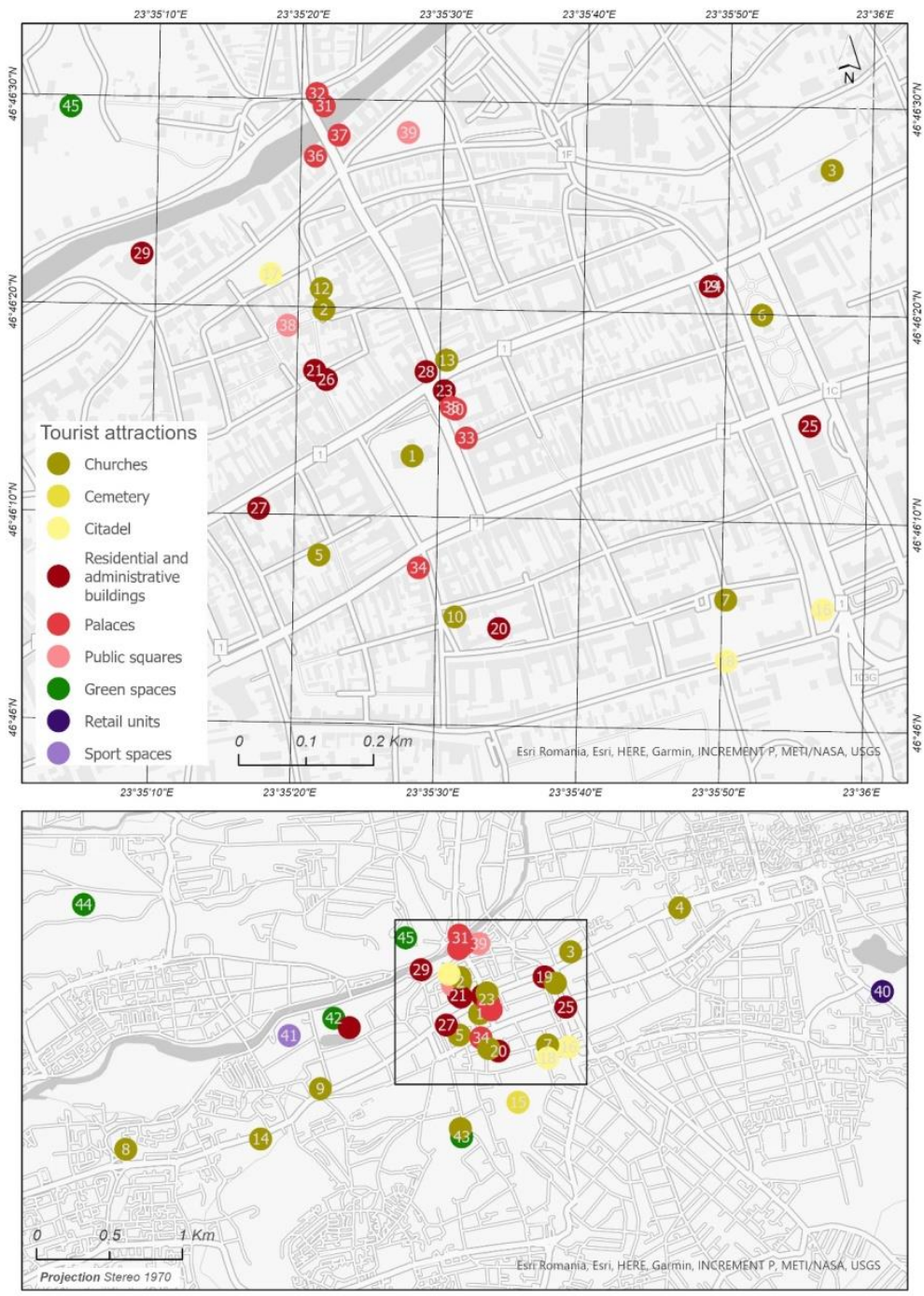

Figure 4. Main tourist attractions in Cluj-Napoca 
1 - St. Michael Church, 2 - The Franciscan Church, 3 - The Hungarian Calvinist Church, 4 - St.Peter Roman-Catholic Church, 5 - The Romanian Greek-Catholic „Christ's Resurrection” Church, 6 - The Orthodox Metropolitan Cathedral, 7 - The Hungarian Calvinist Matia Church , 8 - The Roman-Catholic Calvaria Church, 9 - The Hungarian Calvinist Church, 10 - St. Trinity Roman-Catholic Church, 11 - St. Trinity Romanian Orthodox Church, 12 - The Franciscan Monastery, 13 - The Evangelical Church and parish house, 14 - The Jesuit Monastery, 15 - Central Cemetery, 16 - Tailors' Tower, 17 - The antique and medieval city, 18 - Fragment of the second medieval enclosure, 19 - Cluj-Napoca City Hall, 20 - The BabeșBolyai University main building, 21 - Matei Corvin House, 22 - The Casino in Central Park, 23 - Melody Hotel, 24 - The Local Councill, 25 - The Romanian National Theatre, 26 - The „Sapientia” University, 27 - The Ethnographic Museum of Transylvania, „Reduta” building, 28 - Museum of Pharmacy, 29 - The Hungarian Theatre, 30 - The Art Museum, 31 - Elian Palace, 32 - Berde Palace, 33 - Palaces of the Roman-Catholic Status, 34 - „Continental” Hotel, 35 - Banffy Palace, 36 - Szeki Palace, 37 - Babos Palace, 38 - Museum Square, 39 - Urban complex of Mihai Viteazul Square, 40 - Iulius Mall, 41 - Cluj Arena, 42 - Central Park, 43 - Botanical Gardens, 44 - Hoia-Baciu Forest, 45 - The Citadel

\section{Tourist perception of Cluj-Napoca as a tourist destination}

No less than 50 questionnaires were handed out directly to several foreign tourists, during four months (December 2019, January-March 2020), in order to find out their vision about ClujNapoca as a tourist destination. There were 18 items, which revealed the following aspects:

- most respondents, $90 \%$ of them, think that Cluj-Napoca is a tourist destination, eligible due to prices (including transport) and accessibility. $10 \%$ think that the city cannot be considered as a travel destination yet.

- over $90 \%$ of the respondents haven't visited the city before, and only 4 of them have already visited the city once;

- most tourists recommend Cluj-Napoca as a tourist destination to friends and colleagues, aspect also seen in the ever-growing image of the city;

- the sources of information mentioned by the respondents regarding the choice of a destination were social media (TripAdvisor), tourist guides, friends/colleagues; the city of ClujNapoca is a tourist destination quite visible online. According to TripAdvisor (2020), in Cluj-Napoca there are 295 accomodation units, 54 spaces for rent, 449 food service units (restaurants, bars, coffee shops). Among the activities one can undertake here, there are: tours (51), meeting points and landscapes (41), evening activities (40), activities outside the city (39), interactive activities (30), shopping (25), green areas and parks (14), SPA\&wellness (14), museums (10), means of transport (10), lectures/courses\&workshops (6), tours on boat, water sports (5), shows and concerts (4), casinos and gambling houses (4), travel resources (3) and day trips (1).

- 36 respondents consider the city of Cluj-Napoca is a top tourist destination, similar to other European urban centres, whereas 14 do not agree; moreover, 33 persons think there are premises for the city to become a top tourist destination, whereas the rest of the answers highlight certain impairments that still exist, such as destination visibility;

- tourist respondents (48 persons) chose air transport and only 2 of them considered railway option;

- respondents spent 2-4 days in Cluj-Napoca, the main arguments for chosing the destination were to relax, to discover new places, culture, business or visit friends;

- from the tourist point of view, on a scale from 1 to 5, ratings on the internet vary between 4 and 5, in terms of importance, which highlights the fact that tourist perception is influenced by the experience of other tourists, expressed by means of travel platforms (see the Airbnb experience). 37 respondents prefer meals in food service units other than accomodation structures, whereas 10 would eat within their accomodation units, and the rest of them at friends' places.

\section{Local perception of tourists in the city of Cluj-Napoca}

Among locals, a number of 166 questionnaires were undertaken online (by means of Google Forms) and also directly, with the purpose of catching a better insight on the overtourism phenomenon in Cluj-Napoca. The 20 items used helped us find out the strengths of the city from the perspective of its tourist potential and the use of it. The main elements revealed were the following: 
- a significant percentage of respondents (41\%) have been living in Cluj-Napoca for at least 2 years, most of them in Mănăștur neighbourhood, but also in the city central area (given the fact that student dorms are located in the central area of the city) (Figure 5.1.);

- $69 \%$ of the locals think that Cluj-Napoca holds a well exploited tourist potential, and $21 \%$ consider it is not enough (Figure 5.2.);

- 54\% of the locals say that there are times when the city is overcrowded with tourists (Figure 5.3.), especially in the summer (28\%), in the months of July and August (22\%); the most overcrowded areas are, also in the opinion of local respondents, the historical centre of the city (25\%) and the central park (19\%);

- some locals consider that the city became a tourist destination at the end of an interval of 1-4 years $(47 \%)$, whereas others $(45 \%)$ think that it was no sooner than 4-10 years, and this is why they would recommend it as a tourist destination to family members and friends;

- according to local opinion, Cluj-Napoca is chosen as a tourist destination due to its cultural events $(24 \%)$ sports events (14\%), tourist attractions (17\%), but also due to its being a renowned academic centre $(15 \%)$;
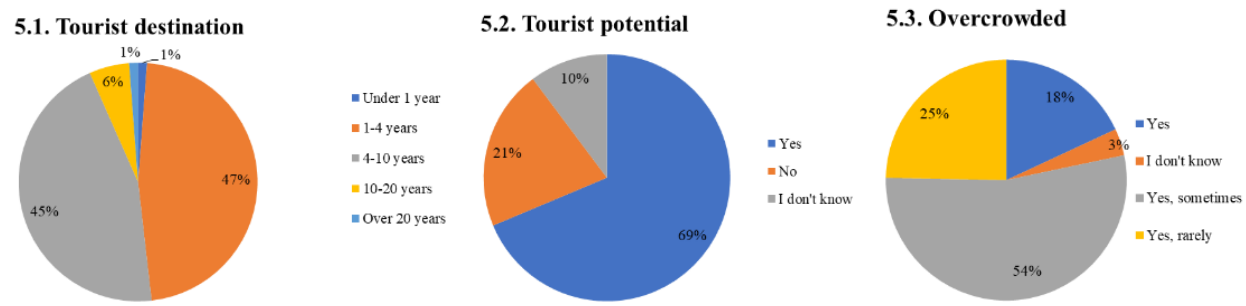

Figure 5. Tourist characteristics of Cluj-Napoca according to local respondents

- the local actors responsible for the promotion of the city as a tourist destination are the City Hall (32\%) and Cluj-Napoca Cultural Centre (20\%) (Figure 6.1.);

- respondents made an ascending order of the benefits brought to the local community as a consequence of tourism development in Cluj-Napoca (Figure 6.2.), i.e., the appearance of new accomodation platforms (20\%), the increase in the number of tourist services (17\%), the increase of accomodation units (15\%), development of the transport system (12\%), image and advertising intake $(11 \%)$, as well as associated events (10\%); as for weaknesses/drawbacks, traffic (30\%) and price increase were mentioned (24\%) (Figure 6.3.);
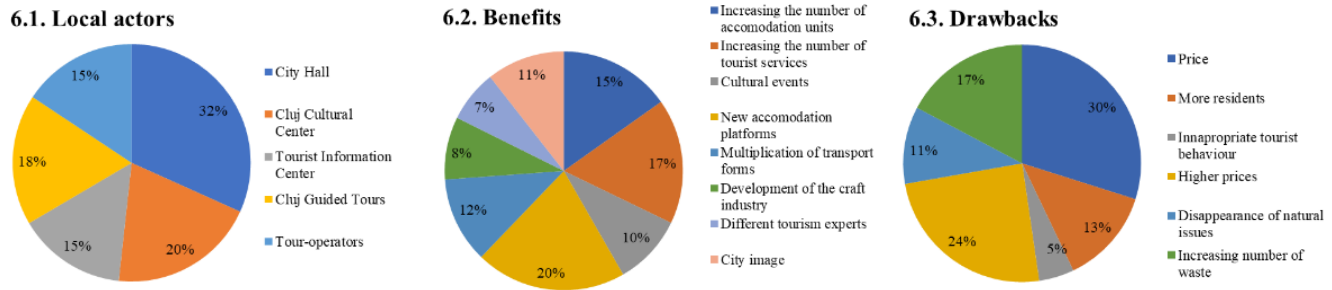

Figure 6. Local actors responsible for the promotion of Cluj-Napoca as a tourist destination, benefits and drawbacks identified by local respondents

- 73\% of the locals wish that the city of Cluj-Napoca became a tourist destination, but $53 \%$ do not know about strategies and measures meant to prevent the effects of overtourism (Figure 7.2.);

$-42 \%$ of the respondents agree upon the introduction of fares on certain tourist attractions, whereas $38 \%$ do not welcome such an initiative (Figure 7.1.); 
- according to local opinions, the most significant measures to be taken in order to avoid overcrowding during intense visiting seasons in Cluj-Napoca (Figure 7.3.), should be the following: traffic restrictions (20\%), prior reservation (18\%), travel industry pricing policy (16\%), tourist number database (15\%), as well as new tourist products and alternative deals (13\%).
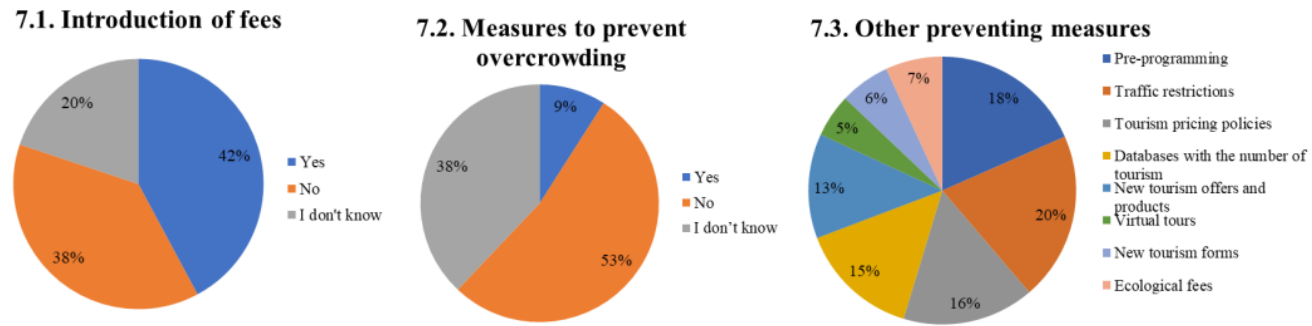

Figure 7. Overtourism preventing measures in the city of Cluj-Napoca

\section{Management strategies for Cluj-Napoca as a tourist destination}

Based on the answers given by respondents, personal observations and the current policies of Cluj-Napoca municipality, we hereby suggest that the following management strategies should be considered for the benefit of the city as a tourist destination:

- the organising of Untold festival in some other location, in a less populated area, to avoid noise pollution that causes discomfort both to the community and the environment built nearby;

- a more efficient promotion at international level by means of the media channels, in order to lure tourists all year long;

- regulations set up for every tourist attraction regarding the number of tourists allowed to do the visit, related to programme and prior reservation;

- visiting fares set up for every tourist attraction, which would increase local income and contribute more efficiently to the restoration of historical and cultural heritage;

- promotion of tourist attractions located in peripheral neighbourhoods of the city and nearby, in order to extend tourist visiting areas;

- promotion of attractions located in areas with little tourist activity, in order to extend tourist visiting areas, diversify possibilities and avoid tourism overcrowding.

\section{CONCLUSIONS}

Cluj-Napoca is one of the most visited cities in Romania, boasting a remarkable tourist potential which is yet to be discovered and exploited. Although at present the overtourism phenomenon cannot be considered in its case, based on the inquiry undertaken, the city has been dealing, in recent years, with an early stage of tourism overcrowding in the summertime; one of the causes is given by the various cultural and artistic events (international and local festivals), which attract a great flow of tourists, a component that might just as well represent a benefit regarding the economic development of the city, of the tourism industry and city visibility. On the other hand, when it comes to infrastructure, the city is not sufficiently prepared yet to welcome and support a great number of tourists, which could lead to overcrowding.

Cluj-Napoca is seen as a European tourist destination both by most tourists and locals, as well. This is an economic benefit given by the tourism industry to the local economic environment, but, in time, it can also be seen as a problem by residents, should it lead to an overcrowded city.

Consequently, a certain percentage of the city's population thinks preventing measures should be considered, such as: visiting fares applied to the most popular tourist attractions, procedures and strategies meant to avoid traffic jams, as well as strategies designed to support price trend related to the development of sustainable tourism. 
The same answers reveal a certain reluctance generated by the potential increase of tariffs and fares, due to an eventual ever-growing competitiveness of the city with other European tourist cities.

In the last decade, the city of Cluj-Napoca has become very visible, both at national and international level, and the ones responsible for this developing process are, according to respondents, Cluj-Napoca City Hall and Cluj-Napoca Cultural Centre; the two institutions are deeply concerned with the promotion of local heritage and attraction of investments meant to contribute to the city development within the tourism industry.

Moreover, the present study may open new development directions, such as identifying new solutions to prevent the overtourism phenomenon or the feasibility analysis of the existing measures and strategies designed to optimise tourist areas.

\section{REFERENCES}

Anuar A.A.N., Hashim I. N., Jaini N., Ridzuan H.F., Suleiman F.C. (2019). The Impact of Overtourism Towards Local Community in Heritage City. Journal of Tourism \& Hospitality, 8(3), 1-5.

Ballester P. (2016). Barcelona and Mass Tourism: Tourismophobia and Coexistence, Grand-Sud Tourism School, Toulouse, Franţa.

Baloglu S., Kozak M. (2011). Managing and Marketing Tourist Destinations. Strategies to Gain a Competitive Edge, Routledge, New York, SUA.

Bogdan E. (2019). Turismul urban [Urban Tourism], Editura Universitară, Bucureşti, Romania.

Bolog C., Bradea A., Toader V. (2014-2020). Strategia de dezvoltare turistică a municipiului Cluj-Napoca [Tourist development strategy of Cluj-Napoca], Cluj-Napoca, Romania.

Bourliataux-Lajoinie S., Dosquet F., Oliver S., Seraphin H., Zaman M. (2019). Destination branding and overtourism, Universitatea din Winchester, UK, Universitatea Perpignan, Franţa, Universitatea Sunderland, UK, Universitatea of Tours, Franţa, ESG Pau, Franţa.

Cave J., Jolliffe L. (2012). Urban Tourism. Tourism: The Key Concepts, Routledge, London, UK.

Coldwell W. (2017). First Venice and Barcelona: Now anti-tourism marches spread across Europe, The Guardian.

Cosma S. (2006). Tourist destination Cluj-Napoca, Romania, Facultatea de Business, Universitatea „Babeş-Bolyai”, Cluj-Napoca.

Cosma S., Negrusa A. (2008). The place of cultural tourism for Cluj-Napoca, Romania as a tourist destination. Wseas Transactions on Business and Economics, 7(5), 407-408.

Egresi I. (2018). „Tourists go home!” - Tourism overcrowding and „tourismophobia” in European cities (Can tourists and residents still co-habitate in the city?, In [Co]Habitation Tactics. Imagining future spaces in architecture, city and landscape, TAW2018 International Scientific Conference from 20th to 23rd September 2018 / POLIS University (pp. 701-714).

Erschbamer G., Innerhofer E., Pechlaner H. (2018). Overtourism: How much tourism is too mисh?, Eurac Research, Centrul pentru Studii Avansate.

Goodwin H. (2017). The Challenge of Overtourism. Responsible Tourism Partnership, Working paper 4, 11-15.

Herman G. V., Banto N., Caciora T., Ungureanu M., Furdui S., Grama V., Buhaș R., Buhaș S. (2020a). Tourism in Bihor County, Romania. Trends and Prospects. Folia Geographica, 62(2), 87-105.

Herman, G.V., Grama, V., Sonko, S.M., Boc E., Băican, D., Garai, L.D., Blaga, L., Josan, I., Caciora, T., Gruia K.A., Grecu, A., \& Peptenatu, D. (2020b). Online Information Premise in the Development of Bihor Tourist Destination, Romania. Folia Geographica, 62, 1, 21-34.

Herman, G.V., Ilieș, D.C., Dehoorne, O., Ilieș, A., Sambou, A., Caciora, T., Diombera, M., Lăzuran, A. (2020c). Emitter and tourist destination in Romania. Baltic Journal of Health and Physical Activity, 12(1), 120-138.

Hospers G.J. (2019). Overtourism in Europe cities: from challenges to coping strategies, CESifo Forum, 20(3): 20-24, Universitatea din Twente, Olanda.

Khanalizadeh B., Yazdi S.K. (2017). Tourism demand: A panel data approach. Current Issues in Tourism, 20(8), 787-800. https://doi.org/10.1080/13683500.2016.1170772.

Kottasová I. (2017). These European cities are fed up with tourists, CNN.

Krugzek Z. (2019). , Overtourism”- Around the definition, Academia Wychowania Fizycznego, Republica Cehă.

Marques L., Richards G. (2019). Overtourism in Lisbon: is culture the salvation?, Olanda.

Martin J.M., Martinez Guaita J.M., Fernandez Salinas J.A. (2018). An Analysis of the Factors behind the Citizen's Attitude of Rejection towards Tourism in a Context of Overtourism and Economic Dependence on This Activity, Sustainability, 10(8), 2851.

Milano C. (2017). Turismofobia: cuando el turismo entra en la agenda de los movimientos sociales, Marea Urbana, 1, 5-8.

Milano C., Novelli M., Cheer J. M. (2018), Overtourism a growing global problem, The Conversation.

Ministerul Culturii (2015). Lista Monumentelor Istorice [List of Historical Monuments].

Mutuku C. (2013). Tourism Destinations. Definitions, Changes and Trends, GRIN Verlag, Munich, Germany. 
Nițulescu D.C. (2006), Procesul de gentrificare a spaţiilor de locuit urbane. Concept și explicaţii alternative [The gentrification of the urban built-up areas. Concept and alternative explanations], Calitatea vieții, XVII(3-4), 281293 (in Romanian).

Paris N. (2017), Tourists have turned Oxford into 'hell' local claim, Telegraph, http://www.telegraph.co.uk/travel/news/oxford-tourist-hell-overcrowding-residents-locals-complain, Accessed date: 20 June 2018.

Parlamentul European (2014-2019), Rezoluţia Parlamentului European din 29 octombrie 2015 referitoare la noile provocări şi concepte pentru promovarea turismului în Europa [European Parliament Resolution on new challenges and concepts for the promotion of tourism in Europe].

Petkar S. (2017), Spain is quite full' tourists urge to travel elsewhere as protests grip holiday hotspots, Express. http://www.express.co.uk/news/world/840042/barcelona-spain-holidaysanti-tourist-protests-go-home-graffitiviolence-tui-travel, Accessed date: 20 June 2018.

Pilato M., Seraphin H., Sheeran P. (2018). Over-tourism and the fall of Venice as a destination, Journal of Destination Marketing and Management, 9, 374-376. https://doi.org/10.1016/j.jdmm.2018.01.011

Popescu A., Grigoraş M. A. (2018). The City of Cluj-Napoca and The Cluj County, Important tourist attractions in Romania, Universitatea de Ştiințe Agricole şi Medicină Veterinară, Bucureşti.

Puşcaş A. (2015). Coloane şi Vitralii. Antichitate şi Evul Mediu. Incursiuni în istoria și cultura turismului urban premodern [Pillars and stain glass. Antiquity and Middle Ages. Incursions in the history and culture of premodern urban tourism], Editura Presa Universitară Clujeană, Cluj-Napoca, Romania.

Taiminen S. (2018). The negative impacts of overtourism on tourism destinations from environmental and socio-cultural perspectives, Teză de diplomă, Facultatea de Business, Arcada.

Submitted:

August 25, 2020
Revised:

November 26, 2020
Accepted and published online

December 21, 2020 